\title{
Micro-study on Travel Process of 'Identity' in Postcolonial Theory in Chinese Context
}

\author{
Jun Tong \\ Zhengzhou Institute of Aeronautic Industrial Management, Zhengzhou, Henan, 450015, China \\ Email: tj@zzia.edu.cn
}

\begin{abstract}
The realization of travel process of word 'identity' chiefly depends on the contact, negotiation and understanding between different cultures. The meanings of the word are not so much 'transformed' when concepts pass from one language to another as invented within the local environment of the latter. This paper mainly discusses the traveling process of the word. In the traveling processes or in the process of adaptation, translation, introduction and domestication, it experienced the process of cultural negotiation and cultural conversation and this kind of process represents as the loss, gain and even changes and transformation of the meaning of the word in the initial cultural backgrounds.
\end{abstract}

Index Terms - translation, travel, translatology, postcolonial theory

\section{THE INITIAL STAGE}

In translingual practice, we must pay attention to the concrete issues of cultural difference, of context and of the discursive possibilities and options available at a specific historical moment. However, when the focus is directed toward the cultural and historical specificities of translation, attention is drawn toward the way how meaning can be and how do they constructed in translation. Therefore, the 'identity' is one of the most essential subjects in post-colonial theory. As we know, only by re-writing one's cultural identity, can one culture identifies its real cultural trait and spirit. Professor Wang Yuechuan also remarked: "By comparing one's own cultural identity with other cultures, 'identity' becomes one nation's collective unconsciousness and centripetal force in spirit, which is the premise to reject cultural hegemony existed between East and West.”(Wang, 1999, p.147) Therefore, it is of vital importance to discuss the key word on issues of 'identity'.

However, in Chinese context, before the year of 1999, there are few translational versions of the works which belong to post-colonial theory. And the understandings of the term 'identity' still not clear. But great changes happened in the year 1999. Two collection theses about the classical theses in post-colonialism in western world got published. One is edited by scholar Zhang Jingyuan called Post-colonial Theory and Literary critics and another is edited by scholar Luo Gang and Liu Xiangyu which named Literary Theory of Post-colonialism. These two books are the earliest translational version of post-colonial theory. Shortly afterwards, Said's masterpiece Orientalism which is also the most classical text in post-colonial theory was translated and published by scholar Wang Yugen. In these books, the most famous critics in post-colonial theory have been introduced into China. Therefore, as one of the most important key words in this theory, 'identity' is also been translated and introduced into China.

In these translated works, the word 'identity' begins its 'traveling'. Different translations such as shenfen, zhengzhishenfen and bentushenfen appeared. The most common translation is shenfen. For example, when translating Lioyd's thesis On the Discourse of Minority: What Should We Do?, the translator translates 'identity' as shenfen:

“一个人可能是一个教授、女性中的一员、一个房客、一个黑人雇员、一个女同性恋者等等。少数者批评话语 在这种情形下可以得到的收获是在于认识到这种身份既不能简化，也是不能相互渗透......” (Luo Gang and Liu Xiangyu, 1999, p.368)

This kind of translation can also be found in the translated version of Bell Hooks' thesis Revolutionary Black Women: Making Ourselves Subject:

“所有这些作品都表现出对权力的一种反应。所有结构都是一次探索，一次完成和一次实现自我的旅程; 所有 一切都涉及到企图挣脱加于黑人和女性身份之上的希冀, 所有作品都反对宣称“我”的奇谈怪论。” (Luo Gang and Liu Xiangyu, 1999, p.399)

This thesis also finds such translation in the translated book Orientalism which is probably the most influential works in Chinese literary circle:

“人类身份不是自然形成的稳定不变的，是人为建构的,有时甚至是凭空生造的.

However, some other translators would like to translate the term as bentushenfen. Such kind of translation can be find in Helen Tiffin's thesis Post-colonialism and Counter-Discourse:

“对文化自我认可（self-ratification）及其本源的民族追求，复制了宗主国的认知过程，在企图构建独立身份的 过程中，再次激活了这些过程的价值和实践。”(Luo Gang and Liu Xiangyu, 1999, p.316-317)

Besides, there exists another translation, that is, zhengzhishenfen. It is not common but still can be found in 
Mohanty's paper Under The Western gazing: Feminism and Colonial Discourse:

“可见，为自身建构反抗的政治身份的策略性联盟可以基于普遍化的、暂时性的联合，不过对这些团体身份的 分析却不能基于普遍化的、非历史化的范畴。”(Luo Gang and Liu Xiangyu, 1999, p.436)

As we know, translation shapes our knowledge of other cultures and should be viewed as a complex set of practices. In such practices, each step such as the selection of the text, the production, circulation and acceptance is governed by wider cultural, social and economic factors. Therefore, no matter these translations are suitable or not, they introduced the original text and help Chinese scholars to understand 'identity'. Through the initial introduction, 'identity' becomes a word connected with politics, culture and race in Chinese literary circle.

\section{The UPSURGE StAGE}

In and after the year of 1999, with the introduction and translation of Edward W. Said's Orientalism, and the publish of the two translated theses collections we mentioned in previous section, many scholars translated, introduced or interpreted the western theory of identity. The word 'identity' was translated and interpreted as shenfen, shenfenrentong, wenhuashenfen or shenfenzhengzhi. This thesis will mainly discuss several most influential works concerned with the translation, interpretation or introduction of the word 'identity'.

In the year of 1999, in the preface of the book The Literary theory of Post-colonialism, scholars Luo Gang and Liu Xiangyu interpret the word 'identity' as wenhuashenfen and minzuwenhuashenfen:

“后殖民理论研究涉及到众多的问题，如文化与帝国主义，殖民话语与西方对东方的文化再现、第三世界的文 化抵抗、全球化与民族文化身份，以及种族、阶级、性别的关系等等。” (Luo Gang and Liu Xiangyu, 1999, p.2)

In the same year, scholar Wang Yuechuan introduced Gayatri C. Spivak's (1942- ) theory in his book Literary Theory of Postcolonialism and New Historicism. In it, he interprets 'identity' as wehuaquanlishenfen and wenhuashenfen:

“后殖民理论是一种多元文化理论，主要研究殖民时期之“后”，宗主国与殖民地之间的文化话语权力关系，以 及有关种族主义、文化帝国主义、国家民族文化、文化权力身份等新问题。”(Wang Yuechuan, 1999, p.1)

“在抹去“臣属”殖民化色彩以恢复本民族“历史记忆”的过程中，如何重新书写自己的文化身份呢? 在斯皮瓦克 看来...”(Wang Yuechuan , 1999, p.56)

Although the translations are different, it can be seen that when the issue of identity travels to China, the power systems in it were immediately emphasized by Chinese scholar. According to these introductions, after the year 1999 , there appears a climax of the discussion about the issue of 'identity'. This thesis will illustrate the various translations of this word which translated by some famous scholars in Chinese critical literary circle or literary commentary from the year 2000 to 2006 so as to clear out the translation trace of the term.

\begin{tabular}{|c|c|c|}
\hline Year & Translations & Translators \\
\hline \multirow[t]{3}{*}{2000} & wenhuashenfen（文化身份） & Liu Shuang（刘双） \\
\hline & shenfenrentong（身份认同） & Chang Qie （昌切） \\
\hline & shenfen(身份) & Guo Jun （郭军） \\
\hline \multirow[t]{3}{*}{2001} & wenhuashenfen（文化身份） & Wei Jiahai（魏家海） \\
\hline & wenhuashenfen（文化身份） & Liu Chuanxia（刘传霞） \\
\hline & wenhuashenfen（文化身份） & Ling Cheng（凌晨） \\
\hline \multirow[t]{2}{*}{2002} & wenhuashenfen（文化身份） & Wang Ning（王宁） \\
\hline & shenfenrentong（身份认同） & Sheng Anfeng（生安锋） \\
\hline \multirow[t]{3}{*}{2003} & wenhuashenfen（文化身份） & Wang Yuechuan（王岳川） \\
\hline & shenfenrentong（身份认同） & Fei Xiaoping（费小平） \\
\hline & shenfenrentong（身份认同） & Wang Qian（王倩） \\
\hline \multirow[t]{4}{*}{2004} & wenhuashenfen（文化身份） & Wu Xiaorong（吴晓蓉） \\
\hline & shenfenrentong（身份认同） & Fei Xiaoping（费小平） \\
\hline & shenfenrentong（身份认同） & Li Jian（李建） \\
\hline & shenfenrentong（身份认同） & Tao Jiajun （陶家俊） \\
\hline \multirow[t]{3}{*}{2005} & shenfenzhengzhi（身份政治） & Chen Taisheng（陈太胜） \\
\hline & shenfenrentong（身份认同） & Zhang Deming（张德明） \\
\hline & shenfenrentong（身份认同） & Wu Xiaoli（巫小黎） \\
\hline \multirow[t]{2}{*}{2006} & wenhuashenfen（文化身份） & Wang Ning（王宁） \\
\hline & wenhuashenfen（文化身份） & Yan Jia（阎嘉） \\
\hline \multirow[t]{2}{*}{2008} & shenfenzhengzhi（身份政治） & Pu Ruoxi（蒲若茜） \\
\hline & shenfenrentong（身份认同） & Yang Chunshi（杨春时） \\
\hline \multirow[t]{2}{*}{2009} & shenfenrentong（身份认同） & Wang Bingbing（王冰冰） \\
\hline & shenfenrentong（身份认同） & Li Chunqin（李春青） \\
\hline
\end{tabular}

From the form we can see that the most common translations are wenhuashenfen and shenfenrentong. Difference translators use different translations according to theirs necessities of discussion and theirs backgrounds of education. The following section will illustrate some dilation of the translations.

Some critics, such as Wang Ning holds that the two translations are the same. Both of the translations wenhuashenfen 
and shenfenrentong suit to the word 'identity' which refers to the initiative characteristics of a nation in literature or literary study:

“将”身份(identity)”概念当作一系列独特的或有着结构特征的一种变通的看法，实际上是将身份的观念当作一 种“建构(construction)...”

“文化身份在不同的场合又可译作文化认同, 主要诉诸文学和文化研究中民族本质特征和带有民族印记的文化 本质特征。” (Wang Ning, 2002, p.4)

While some others such as Qian Chaoying thinks that there is some misunderstanding in the translation of shenfenrentong. He remarks that although rentong is a quite popular word in recent Chinese literary circle, it is not suitable to the translation of the word 'identity'. The reason is that the word rentong contains the meaning of trying to seek sameness with the others while the word 'identity' emphasis the meaning of internality of a person or a nation. Thus, there is no connection between the two words renting (认同) and shenfen (身份):

“身份” (identity,在我国文献中有时被译作 “认同”) 是近年我国文化研究的重要议题。(Qian Chaoying, 2000, p.89)

“使用认同这个中文译词，就其给人一种“有求于外”或“向外求同”的印象...(Qian Chaoying, 2000, p.90)

And what is more, scholar He Qing (河清) even thinks that there are serious misunderstandings about the word 'identity' in the translated version of the works The Clash of Civilizations (《文明的冲突》) written by Huntington (亨 廷顿). He views that it is wrong to translate the term 'cultural identity' as wenhhuarentong (文化认同) and holds that the suitable translation should be wenhuahexing (文化个性).

It can be see in the following writing:

“首先, 中译本把原著全力强调的“文化个性”都误译为“文化认同”, 英文“identity”意思很明确, 是指一个人一件 事物区别于他人他事的内在属性: ‘个性”, ‘已性”, ‘特征”, “身份”等, 无论如何都与 ‘认同' 风马六不相及, 因为 ‘认同’是人们对外在事情表示‘认可赞同’。(He Qing, 1999, p.100-101)

Scholar He Qing views that the translation of shenfenrentong (身份认同) is the action of following the fashion of using the word renting (认同). However, this thesis holds that the translation wenhuahexing (文化个性) is also an ill-defined concept and difficult to achieve most people's agreement.

Although there exists many different opinions, from the form this thesis list above, it can see that most literary scholars agree to scholar Wang Ning’s (王宁) opinion and use the translations interchangeably in literary criticism and comment without choosing.

\section{The DebatABle StAGE}

Since there are various voices about the understanding of the word 'identity', we may need to trace back to the original debate of the word both in western context and in Chinese context.

Originally, in western context, the connotation meaning of the word 'identity' is the confirmation and agreement between individual and specific social culture while the denotation meaning of the word is one cultural subject's collective option between the stronger and the weaker culture. In today's literary circle, there are two groups holding different opinions concerned with the origin of 'identity'. One group thinks that 'identity' can be traced back to The Age of Reason. In that period of time, the importance of human's reason had been high lightened; therefore, enlightenment means the act of rethinking everything including human being itself. People began to rethink the relations between society and oneself as well as the existence of oneself. Another group holds that 'identity' is a newly born idea in popular culture studies. "English scholar Barker suggested that the study of politics, philosophy and linguistics promote the idea of identity as the central subject of culture studies in 1990" (Zhao Xifan, 2004, p.465). They also view that post-modernism is a typical representation of the concept of identity. The concept of 'identity' develops along with the dominant discourse in western society. Mainly, there are three steps worth mention in the evolution. Firstly, subject-centered enlightenment identity. It originated from the subject theory proposed by Rene Descartes (1596-1650). Ultimately, declares Descartes, the only thing one cannot doubt is one's own existence. Certainty and knowledge begin with the self. "I think, therefore I am" thus becomes the only solid foundation which knowledge and a theory of knowledge can be built. For Descartes, the rational essence from superstition, from human passions, and from one's often irrational imagination will allow humankind to discover truth about the physical and one's identity. Later, Immanuel Kant (1724-1804) and Hegel (1770 - 1831) develops Descartes' thought of identity. They holds that human is the master of reason, and one can realize the combination of one's spirit and identity. Secondly, social-centered social identity. From $19^{\text {th }}$ century, influenced by European sociology and socio-psychology, there appears a new concept of identity. The essential concept is that human and society are two different parts in which society plays a more important role. Ultimate reality is material not spiritual. What we know beyond any doubt is that human being exists and lives in social groups. All of our actions and responses are related in some way to our culture and society. Karl Heinrich Marx (1818-1883) and Michel Foucault dedicate a lot to this kind of thinking. The core principles thought is that reality itself can be defined and understood, society shapes our consciousness, social and economic conditions directly influence how and what we believe and value. In a word, one's identity is also determined by society which he or she involves in. Thirdly, decentering post-modern identity. As Fridrich Nietzschr's (1844-1900) Zarathustra, the protagonist of Thus 
spake Zarathustea, proclaims the death of God, the death knell begins to sound for objective reality and ultimate truth. Form Nietzsche to the present, the voice of many scholars declare univocally the death of objective truth and the main stream of western thought turned from entitativism to relativism. "For those post-modern thinkers, there is no such point of reference, for there is no ultimate truth or inherently unifying element in the universe and thus no ultimate reality." (Bressler, 1998, p.119) Since all is difference, each person shapes his or her own concepts of identity. Identity becomes a human construct that is shapes by each individual's dominant social group. Thus, identity is a changing process which hard to define. The meaning of identity becomes a sort of fragment thinking. After the collapse of colonial system, cultural aggression becomes the main measure, therefore, it is natural that the concept of identity attracts most post-colonialists' attraction. Echoed with post-modernism, they also believe that identity cannot be a fixed concept, so they take an anti-entitativism attitude. Till now, the concept of post-colonial identity includes three aspects in western literary circle: ethnic identity which concentrated on the difference of various races; national identity which is absorbed in cultural ideology or its hegemony between the dominant nation and the weaker nation; diaspora identity focus on the identity of a heterogeneous groups who born in the Third world and now lives or works in the First world.

As we mentioned previously, in western context, there are there steps of the issues of identity in western context while it is easy to understand that although shenfen (身份) has already existed in classical Chinese, it is greatly different from the modern western meaning we now refer to. In Chinese context the meaning of the word shenfen (身份) can not only refer to the status, dignity or identity as we usually think and clearly it contains great differences with the word 'identity' in western context.

In order to illuminate different meanings of the word 'identity' before and after 'travel', this paper mainly take the historical and environmental contexts from 1950s to 1990s into consideration. From 1950s to 1970s, due to the leadership of chairman Mao, shenfen(身份) means different classes in society in China. Just as Professor Xu Ben said, the partition of shenfen (身份) determined by political power instead of economic status at that time. Meanwhile, it is gradually inclined to have more relations with people's political standpoint. (Xu Ben, 1996, p.192-196) Therefore, the partition of classes was mainly determined by the special political ideology at that moment. Shenfen (身份) possessed strong political color. There were strict borderlines among varying kinds of shenfen(身份). Some kinds of shenfen (身 份), such as workers, farmers, and soldiers, are superior to other kinds of shenfen (身份), such as intellectuals and businessmen. This kind of guide line can be found in chairman Mao's writing:

“这时, 只有在这时, 我才根本地改变了资产阶级学校所教给我的那种资产阶级和小资产阶级的感情, 这时, 拿未改造的知识分子和工人农民相比, 就觉得知识分子不干净了, 最干净的还是工人, 农民, 尽管他们手是黑 的，脚上有牛屎，还是比资产阶级和小资产阶级知识分子干净。”

Thus, before 1980s, the problem of shenfen (身份) is always determined by political powers and everybody's shenfen (身份) is prescriptived by society. Nobody needs to ask the question: “who am I?" because the society already answered the question for everybody. It is merely impossible and unnecessary for individuals to think and try to answer the question.

However, from 1980s, due to the political and economic reform and opening policy, the old opinion of shenfen (身份) faced great challenges. Although the issue of shenfen (身份) was still bound to political powers, it became more fluid and changeable. We can see this change in the following statement:

“在中国，自八十年代以来，人们的社会身份认同开始面临前所未有的危机。这种危机在九十年代进一步深化 和复杂化...... - 方面, 在这个时期, 身份的分辨和确定从前年代形式向现代形式转变, 它表现为社会身份开始 具有前所未有的建构性、流动性和变化性......另一方面, 身份仍然和官方政治对社会的控制紧密地联系在一 起.....” (Xu Ben, 1996, p.193)

Among these changes, the intellectuals felt they are facing shenfen (身份) crisis for they gradually lost their safety in economy after the reform. Therefore, more and more intellectuals try to modulate their shenfen (身份) by their knowledge. Identity becomes a human construct that is determined by each individual's dominant social groups. Just at that time, western theory of identity has been introduced to China and acted as the instruments by Chinese intelligentsia. The word identity was borrowed into Chinese and shenfen (身份) began to take up the English connotation. As we know, in western theory, the issue of identity has a deep philosophical root and post-colonial identity mainly includes three aspects: ethnic identity, national identity and diasporie identity, so the two words 'shenfen (身份)' and 'identity' have totally different connotation and denotation in respective cultural context, then why did Chinese scholars equals identity with shenfen (身份), wenhuashenfen (文化身份) or shenfenrentong (身份认同)?

Obviously they carried out such act intentionally not mistakenly. The reason is that "Identity, is a kind of historically constructed artifact... in a word, identity is closely related to power relations in every society and definitely not a pure academic wollgathering." According to his or hers necessaries of discussion, each scholar chooses a kind of translation. For example, scholar Wang Ning holds that the function of the term 'identity' in post-colonial theory mainly lies in comparing different texts between east and west. It should be work for the comparative literature:

“在文化身份在不同的场合又可译作文化认同，主要诉诸文学和文化研究中民族本质特征和带有民族印记的文 化本质特征。比较两种不具有任何事实上影响的文本时, 学者们完全可以侧重于比较这种本质的差异而寻找某 
种具有共性和本质特征的相同点, 当然这种认同主要是审美上的认同。”(Wang Ning, 2000, p.4)

Thus, according to his writing, since the issue of identity mainly belongs to literary discussion, it is not of great importance whether the translation should be shenfen (身份), wenhuashenfen (文化身份) or shenfenrentong (身份认 同).

However, scholar Qian Chaoying (钱超英) thinks that the term identity introduced from post-colonial theory should be used in diaspora study.

“身份”概念尤其便于用来考察和研究那些在明显不同的“文化历史设定”的裂缝之间漂移运动的“主体——移 民’、“问题群体”, 在全球化中经历急具社会转型的民族——所必然面临的身后重建经验。(Qian Chaoying, 2000, p.90)

Therefore, he views that the translations such as shenfenrentong (身份认同) and shenfengexing (身份个性) are not suitable although he doesn't propose his translation. All in all, the issue of identity has been among the forms of Chinese intellectuals' probe into their selves and their literary discussions.

There is some common feature among these various translations in Chinese context. That is, when the theory traveled to China, the philosophical base has been neglected and Chinese scholar paid most attention to only one aspect of post-colonial identity, that is, national identity. So let's go deep to find out reasons for such phenomenon. Being a semi-colonial country, China has its peculiar features when facing western theory of identity. Firstly, being a semi-colonial country, Chinese has no explicit favor for ethnic identity. Secondly, being the weaker side of the cultural hegemony, Chinese scholars admire as well as envy and resist western theory. Naturally, nationalist identity awakened by the stimulation of western theory. Therefore, when the theory traveled to China, the philosophical base has been neglected and Chinese scholar paid most attention to national identity. We can see this phenomenon from scholar Tao Jiajun's (陶家俊) remarks, in his words:

“讨论后殖民认同就要涉及到国家和民族的概念...作为政治共同体, 民族国家一方面依靠国家机器维护其政治 统一, 另一方面, 作为想象共同体, 它又需依赖本民族的文化传承, 确保其文化统一。” (Zhao Xifan, 2004, p.469)

Nowadays, many critics became aware of this tendency. Such as Lan Aiguo (蓝爱国) pointed out: "Whenever we Chinese taking about the problems of identity, the first thing came to our mind is the opposition of the East and the West." Thirdly, it is popular in literally circle to emphasis on the power relations between east and west. All these reasons can explain why Chinese scholars emphasized national identity particularly.

There are also historical and environmental reasons behind the surface. At that time, due to the political system, intellectuals were far from the dominant power relations. If they want to enter the main discourse which dominated by political circle, they must find some other discourse to support them. Then, they used the empowerment of western theory of identity and paid special heed to national identity so as to enter the main discourse and raise their self-esteem as well as social status. We can find some supports in Professor Xu Ben's writing:

“一些知识分子发现了“本土”这个民族身份对于处于身份危机之中的中国知识分子的“增势(empowerment)'作 用, 并有意识地运用这种身份来提升他们的自尊和社会地位。”(Xu Ben, 1996, p.199-200)

The theory of Foucault's knowledge archaeology helps explain the changes in the discourse around identity. For Foucault, "history is the complex relationship of a variety of discourses or the various ways-- artistic, social, political-that people think and talk about their world." (Bressler, 1988, p.242) Seen from Foucault's point of view, the travel process can also act as a form of power. The traveling process ultimately determines what takes place in each culture or society. Therefore, the traveling process of the word 'identity' is a process full of contact, complement and negotiation among the history, context and the intellectuals. Seen from the traveling process of the term 'identity', we can find that there are complex relations between the concept between East and West as well as national and global. It is true to say that: "the complex relations influence the essential issue of Chinese ideological system, that is, the understanding and construct of Chinese own cultural studies. The study of identity is also the study of national culture."

\section{REFERENCES}

[1] Bressler, Charles. (1998). Literary Criticism: An Introduction to Theory and Practice. Houghton: Houghton College.

[2] Foucault, Michel. (1972). The Archaeology of Knowledge, trans. A. M. Sheridan Smith. New York: Pantheon Books.

[3] He Qing. (1999). The Character and Identity of Culture. Journal of Reading Books, Issue 4.

[4] Liu, Lydia H. (1995). Translingual Practice: Literature, National Culture, and Translated Modernity--China, 1900-1937,California: Stanford University Press.

[5] Lin, Dajing. (2008). Studies on Inter-culture Translation. Fujian: Fujian People's Press.

[6] Luogang \& Liu, Xiangyu. (1999). Post-colonial Cultural Theory. Beijing: China Social Sciences Publishing House.

[7] Luogang \& Liu, Xiangyu. (2001). Papers on Cultural studies. Beijing: China Social Sciences Publishing House.

[8] Nida, E. (2001). Language and Culture: Context in Translating. Shanghai: Shanghai Foreign Language Education Press.

[9] Qian Chaoying. (2000). Concept and Consciences of Identity. Journal of Shengzhen University, Issue 4.

[10] Said, Edward. (1979). Orientalism. New York: Vintage.

[11] Venuti, Lawrence. (1995). The Translator's Invisibility: A History of Translation. London and New York: Routledge.

[12] Wang Ning (2002). The Construction of Cultural Identity and Chinese Literary Crisis. Journal of Gansu Social Sciences, Issue 4.

[13] Wang, Yuechuan. (1999). Post-colonial Theory and New Historical Criticizes. Jinan: Shandong Education Publishing House. 
[14] Williams, Raymond. (1983). Keywords: A Vocabulary of Culture and Society. New York: Oxford University Press3.

[15] Xuben. (1996). On Post-modernism and Post-colonialism. Beijing: China Social Sciences Publishing House.

[16] Zhao Xifang. (2004). Translation and Dialogue in New Era. Beijing: China Social Sciences Publishing House.

Jun Tong was born in Henan, China in 1980. She received her M.A. degree in English language and literature from Guizhou University, China in 2008.

She is currently a lecturer in English Department of Zhengzhou Institute of Aeronautic Industrial Management, Zhengzhou, China. Her research interests include English literature and translation. 